\title{
Prevalence of cytolethal distending toxin (cdt) genes and CDT production in Campylobacter spp. isolated from Danish broilers
}

\author{
DANG D. BANG, FLEMMING SCHEUTZ*, PETER AHRENS†, KARL PEDERSEN, JENS BLOM* and \\ MOGENS MADSEN \\ Department of Poultry, Fish, and Fur Animals, Danish Veterinary Laboratory, Hangøvej 2, DK-8200 Aarhus N, \\ * International Escherichia and Klebsiella Center (WHO), Statens Serum Institut, Artillerivej 5, DK-2300 \\ Copenhagen S, †Department of Microbiology, Danish Veterinary Laboratory, Bulowsvej 27, DK-1790 \\ Copenhagen V and Department of Virology, Statens Serum Institut, Artillerivej 5, DK-2300 Copenhagen S, \\ Denmark
}

\begin{abstract}
The pathogenesis of campylobacter infection in man is largely unknown, although cytolethal distending toxin (CDT) has been incriminated as a virulence factor. However, little is known about the cdt genes in Campylobacter spp. isolated from broiler chickens. A total of 350 cloacal swabs was collected and tested by conventional culture and PCR. Of the 114 Campylobacter isolates obtained, $101(88.6 \%)$ were identified as $C$. jejuni and $13(11.4 \%)$ as $C$. coli by conventional methods. cdt genes were detected by PCR in all the isolates except one $C$. jejuni isolate. Cytotoxic effects were produced in a Vero cell line, by 100 of the $C$. jejuni isolates. In contrast, $10 C$. coli isolates produced much lower levels of toxin and 3 produced no detectable toxin. These results confirm the common occurrence of campylobacter infection in chickens and indicate that cdt genes are commonly present in both $C$. jejuni and $C$. coli isolates from broilers, but that there are distinct differences in CDT production in these two closely related species.
\end{abstract}

\section{Introduction}

Campylobacteriosis is one of the most common bacterial intestinal disorders of man in many industrialised countries. In the USA, 2-8 million cases, which cause an estimated 200-800 deaths, are reported annually $[1,2]$. In Denmark, human campylobacteriosis has recently increased rapidly from 1129 reported cases in 1992 [3] to $>4000$ cases in 1999 [4]. Large outbreaks of human campylobacteriosis are rare, but sporadic cases are common and are often linked to the consumption of undercooked food products contaminated with campylobacters [5-7]. A high prevalence of campylobacter infection has been reported in poultry flocks in several countries, e.g., the USA [8] and Denmark [9]. Campylobacters can survive during poultry processing and the bacteria may spread to uncontaminated poultry products. The most common cause of Campylobacter-induced human enteritis is $C$. jejuni, which may account for as much as $90 \%$ of all

Received 20 Dec. 2000; revised version received 15 June 2001; accepted 20 June 2001.

Corresponding author: Dr D.D. Bang (e-mail: ddb@svs.dk).
Campylobacter isolates from broilers in Denmark [4] and other industrial countries [7, 10, 11].

In poultry, Campylobacter spp. are considered to be commensals because the infection does not cause any clinical symptoms [12]. However, the specific virulence mechanisms of Campylobacter spp. have not yet been adequately elucidated in human disease, although several virulence determinants have been proposed for Campylobacter spp., including flagella-mediated motility, adherence to the intestinal mucosa, invasive capability and the ability to produce toxin [13-15].

The best characterised of the proposed campylobacter toxins is the cytolethal distending toxin (CDT), which has been detected in several Campylobacter spp. $[16,17]$. CDT causes progressive cellular distention and ultimately death in Chinese hamster ovary $(\mathrm{CHO})$, Vero, HEp-2, HeLa and Caco-2 cells [16-20].

The $C$. jejuni $c d t$ genes have been cloned and sequenced [21]; they consist of three adjacent genes, $c d t \mathrm{~A}, \quad c d t \mathrm{~B}$ and $c d t \mathrm{C}$, that encode proteins with predicted mol. wts of $c$. 30, 29 and $21 \mathrm{kDa}$, respectively. The functions of the CDT proteins are unknown. 
However, it has been shown recently by DNA content analysis of cells treated with campylobacter CDT that the CDT causes several cell types to become blocked in either $\mathrm{G} 2$ or early $\mathrm{M}$ phase of their cell cycle before cell division $[20,22]$. This indicates that the action of CDT differs from that of other bacterial toxins $[20,23,24]$.

Little is known about the prevalence of the $c d t$ genes among Campylobacter spp. isolated from broilers. In the present study, Campylobacter spp. were isolated from individual chickens and identified by conventional microbiological culture and by PCR. The $c d t$ genes were detected by PCR and the CDT activity of culture supernates was tested in tissue cultures.

\section{Materials and methods}

\section{Broiler samples}

Ten cloacal swabs from each of 35 chicken broiler flocks were collected randomly at the abattoir immediately before slaughter. The swabs were transferred from the abattoir to the laboratory by mail in screw-cap centrifugation tubes containing $12 \mathrm{ml}$ of Brain Heart Infusion (BHI) transport medium (BHI broth; Difco) supplemented with sterile defibrinated calf blood $5 \% \mathrm{v} / \mathrm{v}$, and agar

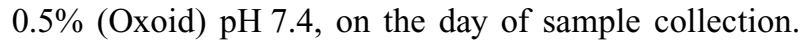
On arrival at the laboratory, each swab was transferred immediately to $0.3 \mathrm{ml}$ of sterile water and left at room temperature for 10-20 min to release the bacteria. The suspensions of faeces and bacteria were used directly for detection of campylobacters.

\section{Isolation and identification of Campylobacter spp. by conventional culture methods}

A loopful $(10 \mu \mathrm{l})$ of the suspensions was spread on the surface of a charcoal cefoperazone deoxycholate agar (CCDA) plate (Oxoid CM 739 with cefoperazone selective supplement SR 155E). The plate was incubated in micro-aerobic conditions $\left(\mathrm{O}_{2} 6 \%, \mathrm{CO}_{2} 6 \%, \mathrm{H}_{2}\right.$ $4 \%$ and $\mathrm{N}_{2} 84 \%$ ) at $42^{\circ} \mathrm{C}$ for $48 \mathrm{~h}$. Colonies suspected as being Campylobacter spp. were examined for cell morphology by phase-contrast microscopy (Olympus B 201). The isolates were purified further on blood agar plates (BA; Blood Agar Base No. 2, Oxoid, supplemented with sterile defibrinated calf blood $5 \%$ ). Single colonies were picked and streaked on wet BA plates, and further characterised to species level by their catalase reaction, ability to hydrolyse hippurate and indoxyl acetate and their susceptibility to nalidixic acid and cephalothin according to standard procedures $[25,26]$. Isolates were stored with glycerol $15 \%$ at $-80^{\circ} \mathrm{C}$ until required for further investigations.

\section{Bacterial reference strains}

Reference strains C. jejuni CCUG 11284, C. coli CCUG 11283, the verotoxin-producing Escherichia coli strain H 19 (SSI no. D2165, serotype O26:H11) and the CDT-producing E. coli strain E6468/62 (SSI no. D2253, serotype O127:H6) were used as controls for the PCR studies and for the cell culture assays (see below). The strains were stored in serum-broth containing glycerol $15 \%$ at $-80^{\circ} \mathrm{C}$.

\section{DNA techniques}

Total bacterial cell DNA was isolated by QIA Amp kit (QIAGEN, Germany) from overnight cultures on BA. The DNA was eluted in $200 \mu \mathrm{l}$ of sterile water and stored at $-20^{\circ} \mathrm{C}$. Restriction endonucleuses were used in accordance with the supplier's specifications (New England Biolabs).

\section{Identification of Campylobacter spp. by PCR}

For species identification, a PCR was performed initially with the universal Campylobacter 16S rRNA primer [27] for the detection of the Campylobacter genus. All PCR-positive samples were then subjected to a second PCR with different 16S rRNA speciesspecific primer sets $[27,28]$ for different Campylobacter spp. (Table 1). For differentiation of C. jejuni from C. coli, a third PCR was performed with hippuricase gene primers [29]. The hippuricase gene has been shown to be specific for C. jejuni $[29,30]$. The PCR was performed in a Peltier Thermal Cycler PTC-200 (MJ Research, Massachusetts, USA) for 30 cycles. The PCR conditions for each primer set are presented in Table 1. All PCR mixtures $(50 \mu \mathrm{l})$ contained $0.2 \mathrm{mM}$ (each) dATP, dCTP, dGTP and dTTP; $1.5 \mathrm{mM} \mathrm{MgCl}_{2}$; $5 \mu \mathrm{l}$ (20 pmole) of each primer (DNA Technology, Aarhus, Denmark); $1 \times$ Taq DNA polymerase buffer and Taq DNA polymerase (Boehringer-Mannheim, Germany) $0.5 \mu \mathrm{l}$ (2.5 U).

\section{Detection of cdt genes from Campylobacter isolates by PCR and nucleotide sequencing of the cdtB gene}

Chromosomal DNA from C. jejuni and C. coli isolates was used as templates in PCR reactions with the primers VAT2 and WMI1 (Fig. 1) complementary to the $c d t \mathrm{~B}$ gene as described by Pickett et al. [21]. The parameters of PCR for $c d t$ gene detection reactions were 30 cycles of $94^{\circ} \mathrm{C}$ for $1 \mathrm{~min}, 42^{\circ} \mathrm{C}$ for $2 \mathrm{~min}$ and $72^{\circ} \mathrm{C}$ for $3 \mathrm{~min}$.

The $c d t \mathrm{~B}$ gene PCR-negative Campylobacter isolates were further screened for the $c d t$ genes with the primers GNW and IVH, complementary to the sequences of the $c d t \mathrm{~A}$ gene or with the primers VAT2 and LPF-X, complementary to the sequences of the $c d t \mathrm{~B}$ and $c d t \mathrm{C}$ genes, respectively [21] (Fig. 1).

For DNA sequencing of the $c d t \mathrm{~B}$ gene, PCR amplification products were purified with a QIA Quick Spin Column (QIAGEN). DNA sequencing was performed 
Table 1. List of primers, size of amplicons and PCR conditions used in this study

\begin{tabular}{|c|c|c|c|}
\hline PCR reaction no. & Primers & Sequences and amplicon size & PCR conditions [reference] \\
\hline 1 & $\begin{array}{l}\text { 16S rRNA } \\
\text { (for Campylobacter genus) }\end{array}$ & $\begin{array}{l}\text { 5'-GGATGACACTTTTCGGAGC-3' } \\
\text { 5'-CATTGTAGCACGTGTGTC-3' } \\
\text { Amplicon: } 816 \mathrm{bp}\end{array}$ & $\begin{array}{l}94^{\circ} \mathrm{C} 1 \mathrm{~min} \\
55^{\circ} \mathrm{C} 1 \mathrm{~min}, 25 \text { cycles } \\
72^{\circ} \mathrm{C} 1 \mathrm{~min} \\
{[27]}\end{array}$ \\
\hline 2 & $\begin{array}{l}\text { 16S rRNA } \\
\text { (for } C . \text { jejuni, C. coli) }\end{array}$ & $\begin{array}{l}\text { 5'-AATCTAATGGCTTAACCATTA-3' } \\
\text { 5'-GTAACTAGTTTAGTATTCCGG-3' } \\
\text { Amplicon: } 937 \text { bp }\end{array}$ & $\begin{array}{l}94^{\circ} \mathrm{C} 1 \mathrm{~min} \\
58^{\circ} \mathrm{C} 1 \mathrm{~min}, 25 \text { cycles } \\
72^{\circ} \mathrm{C} 1 \mathrm{~min} \\
{[28]}\end{array}$ \\
\hline 3 & $\begin{array}{l}\text { 16S rRNA } \\
\text { (for } C \text {. fetus) }\end{array}$ & $\begin{array}{l}\text { 5'-GCAAGTCGAACGGAGTATTTA-3' } \\
\text { 5'-GCAGCACCTGTCTCAACT-3' } \\
\text { Amplicon: } 997 \text { bp }\end{array}$ & $\begin{array}{l}94^{\circ} \mathrm{C} 1 \mathrm{~min} \\
65^{\circ} \mathrm{C} 1 \mathrm{~min}, 25 \text { cycles } \\
72^{\circ} \mathrm{C} 1 \mathrm{~min} \\
{[27]}\end{array}$ \\
\hline 4 & $\begin{array}{l}\text { 16S rRNA } \\
\text { (for } C \text {. hyointestinalis) }\end{array}$ & $\begin{array}{l}\text { 5'-GCAAGTCGAACGGAGTATTTA-3' } \\
\text { 5'-GCGATTCCGGTCTCATGCTC-3' } \\
\text { Amplicon: } 1287 \mathrm{bp}\end{array}$ & $\begin{array}{l}94^{\circ} \mathrm{C} 1 \mathrm{~min} \\
65^{\circ} \mathrm{C} 1 \mathrm{~min}, 25 \text { cycles } \\
72^{\circ} \mathrm{C} 1 \mathrm{~min} \\
{[27]}\end{array}$ \\
\hline 5 & $\begin{array}{l}\text { 16S rRNA } \\
\text { (for C. upsaliensis) }\end{array}$ & $\begin{array}{l}\text { 5'-GGGACAACACTTAGAAATGAG-3' } \\
\text { 5'-CACTTCCGTATCTCTACAGA-3' } \\
\text { Amplicon: } 878 \mathrm{bp}\end{array}$ & $\begin{array}{l}94^{\circ} \mathrm{C} 1 \mathrm{~min} \\
60^{\circ} \mathrm{C} 1 \mathrm{~min}, 25 \text { cycles } \\
72^{\circ} \mathrm{C} 1 \mathrm{~min} \\
{[27]}\end{array}$ \\
\hline 6 & $\begin{array}{l}\text { 16S rRNA } \\
\text { (for } C \text {. helviticus) }\end{array}$ & $\begin{array}{l}\text { 5'-GGGACAACACTTAGAAATGAG-3' } \\
\text { 5'-CCGTGACATGGCCTGATTCAC-3' } \\
\text { Amplicon: } 1225 \text { bp or } 1375 \text { bp }\end{array}$ & $\begin{array}{l}94^{\circ} \mathrm{C} 1 \mathrm{~min} \\
60^{\circ} \mathrm{C} 1 \mathrm{~min}, 25 \text { cycles } \\
72^{\circ} \mathrm{C} 1 \mathrm{~min} \\
{[27]}\end{array}$ \\
\hline 7 & $\begin{array}{l}\text { 16S rRNA } \\
\text { (for } C \text {. lari) }\end{array}$ & $\begin{array}{l}\text { 5'-CAAGTCTCTTGTGAAATCCAAC-3' } \\
\text { 5'-ATTTAGAGTGCTCACCCGAAG-3' } \\
\text { Amplicon: } 561 \mathrm{bp}\end{array}$ & $\begin{array}{l}94^{\circ} \mathrm{C} 1 \mathrm{~min} \\
55^{\circ} \mathrm{C} 1 \mathrm{~min}, 25 \text { cycles } \\
72^{\circ} \mathrm{C} 1 \mathrm{~min} \\
{[27]}\end{array}$ \\
\hline 8 & $\begin{array}{l}\text { Hip } \mathrm{O} \\
\text { (for } C \text {. jejuni) }\end{array}$ & $\begin{array}{l}\text { 5'-GTACTGAAAATTTAGTGGCG-3' } \\
\text { 5'-GAGCTTTTAGCAAACCTTCC-3' } \\
\text { Amplicon: } 1130 \mathrm{bp}\end{array}$ & $\begin{array}{l}94^{\circ} \mathrm{C} 1 \mathrm{~min} \\
55^{\circ} \mathrm{C} 1 \mathrm{~min}, 25 \text { cycles } \\
72^{\circ} \mathrm{C} 1 \mathrm{~min} \\
{[29]}\end{array}$ \\
\hline 9 & $C d t \mathrm{~B}$ toxin gene & $\begin{array}{l}\text { 5'-GTTAAAATCCCCTGCTATCAACCA-3' } \\
\text { 5'-GTTGGCACTTGGAATTTGCAAGGC-3' } \\
\text { Amplicon: } 495 \mathrm{bp}\end{array}$ & $\begin{array}{l}94^{\circ} \mathrm{C} 1 \mathrm{~min} \\
42^{\circ} \mathrm{C} 2 \mathrm{~min}, 30 \text { cycles } \\
72^{\circ} \mathrm{C} 3 \mathrm{~min} \\
{[21]}\end{array}$ \\
\hline
\end{tabular}

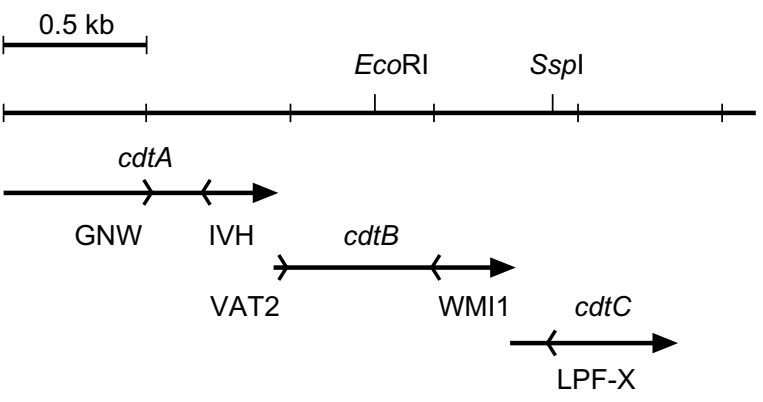

Fig. 1. Map of $C$. jejuni $c d t$ genes and locations of the PCR primers. Arrows indicate the size and direction of transcription of the $c d t$ genes. Large arrowheads indicate the location and orientations of the primers [21], and this study].

with an ABI automatic sequencer with the Prism BigDye terminator cycle sequencing kit (Applied Biosystem, Foster City, CA, USA) and the $c d t$ B gene primers (Table 1).

\section{Preparation of cell-free bacterial culture supernates for toxin assays}

Cell-free bacterial culture supernates were prepared according to the method described by Florin and Antillon [18], with modifications. Bacteria from frozen stocks were inoculated on wet BA plates and incubated under micro-aerobic conditions at $42^{\circ} \mathrm{C}$ for $48 \mathrm{~h}$. A loopful of bacteria was transferred to a sterile 2-ml Eppendorf tube containing $1 \mathrm{ml}$ of Veal Infusion Broth (VIB; Difco) $25 \mathrm{~g} / \mathrm{L}$ and the bacterial suspension was vortex mixed. The tubes were incubated at $42^{\circ} \mathrm{C}$ for $72 \mathrm{~h}$ under micro-aerobic conditions. To enable a comparison of the ability of different strains to produce CDT, the bacterial suspensions were adjusted to a defined optical density corresponding to $10^{8} \mathrm{cfu} / \mathrm{ml}$ at $\mathrm{OD}_{600}$ with an ELISA reader (Multiskan MS Labsystem, Life Science Inter. Comp. Finland). The cell-free bacterial culture supernates were collected by centrifugation at $13000 \mathrm{rpm}$ for $5 \mathrm{~min}$ at $5^{\circ} \mathrm{C}$ and filter sterilised $(0.22 \mu \mathrm{m}$, Millipore, USA). Ten $\mu \mathrm{l}$ of the filtrates were inoculated onto BA plates and incubated at $37^{\circ} \mathrm{C}$ under both aerobic and micro-aerobic conditions to test for sterility.

\section{Detection of CDT activity by cell culture assays}

Nine-day-old chicken embryos were used to prepare cell lines according to the method described by Schat and Purchase [31]. The cells were used at a concentration of $0.5 \times 10^{8}$ cells $/ \mathrm{ml}$.

Vero cells were prepared according to Konowalchuk et al. [32], with modifications. The cells were cultivated in Eagle's Minimal Essential Medium (MEM) with heat 
inactivated $\left(56^{\circ} \mathrm{C}, 30 \mathrm{~min}\right)$ fetal calf serum (FCS) $10 \%$, $4 \mathrm{mM}$ L-glutamine and gentamicin $60 \mathrm{mg} / \mathrm{L}$. Overnight cultures in plastic flasks were trypsinised with $4 \mathrm{ml}$ of trypsin $20 \%$ for 5-6 min. After removal of the trypsin, the cells were suspended in $15-20 \mathrm{ml}$ of MEM to produce a final concentration $0.1 \times 10^{8}$ cells $/ \mathrm{ml}$. Samples of the cell suspension $(150 \mu \mathrm{l})$ were transferred to each of 96 wells in a microtitration plate and incubated overnight at $37^{\circ} \mathrm{C}$ in a moist chamber. The following day, the medium was replaced with fresh MEM containing FCS 3\%, $200 \mu \mathrm{l} /$ well. Then $30 \mu \mathrm{l}$ of cell-free bacterial culture supernate were added to each well. Each sample was added to duplicate wells at the desired dilutions. Duplicate assays of a given supernate were highly reproducible even after storage for 4-6 months at $-20^{\circ} \mathrm{C}$. Toxin production by each isolate was tested in at least three independent assays. Repeat assays of a given isolate with culture supernates prepared at different times did not vary by more than one dilution step. Supernates from a culture of the verotoxin-producing E. coli H19 (D2165, O26:H11) and the CDT-producing E. coli E6468/62 (D2253, O127:H6) strains were used as positive controls and VIB medium as a negative control. The control samples were always included in duplicate wells on each plate. The cytotoxic effects were monitored daily for 4-6 days by phase-contrast microscopy.

The CDT titres were determined by performing twofold dilutions of the bacterial cell-free supernates in 96-well microtitration plates. The titre of a given sample was defined as the highest dilution that caused at least $30 \%$ of the cells in a well to be rounded or distended, as described previously [33].

\section{Results}

Isolation and identification of Campylobacter spp. isolates from faecal samples

Of the 350 samples tested, 111 (32\%) samples were positive for Campylobacter spp. The method for isolation of Campylobacter spp. was designed to isolate $1 \mathrm{cfu}$ of a Campylobacter sp./chicken. However, if there appeared to be more than one type of colony morphology on the CCDA or BA plates then all the colony types were examined further. This resulted in the additional testing of one isolate from each of three chickens; two of these chickens carried two different $C$. jejuni isolates and one chicken carried $C$. jejuni and $C$. coli. Overall, 114 Campylobacter isolates were obtained from 15 broiler flocks.

A comparison of the methods for identification of Campylobacter isolates is presented in Table 2. By means of conventional culture and identification methods, $101(88.6 \%)$ isolates were identified as $C$. jejuni and $13(11.4 \%)$ were identified as $C$. coli. With the PCR methods, 114 samples were positive with the $16 \mathrm{~S}$ rRNA universal primer that is specific for the Campylobacter genus. The second PCR was performed with different $16 \mathrm{~S}$ rRNA species-specific primers. All of the 114 samples were PCR-positive with the $16 \mathrm{~S}$ rRNA primers specific for $C$. jejuni and $C$. coli, whereas no specific PCR products were detected with the 16S rRNA primers specific for other Campylobacter species (Table 2). C. jejuni and C. coli were differentiated by a third PCR with hippuricase gene primers. Of 114 samples that were PCR-positive for the specific C. jejuni and C. coli $16 \mathrm{~S}$ rRNA primers, 103 $(90.4 \%)$ samples were positive with hippuricase primers and $11(9.6 \%)$ were negative (Table 2$)$.

\section{Detection of cdtB gene sequences from Campylobacter isolates by PCR}

The primers VAT2 and WMI1 were used to screen for the presence of $c d t \mathrm{~B}$ sequences in all 114 isolates (Table 3). A single PCR product of c. $500 \mathrm{bp}$ was observed in the PCR reaction with DNA from $98 C$. jejuni and 13 C. coli isolates (Fig. 2). Three isolates, SC-6, SC-61 and SC-770, were $c d t$ B-PCR-negative. The PCR amplicons observed were very close to the expected size of $495 \mathrm{bp}$ for a product amplified from

Table 2. Comparison of methods for identification of Campylobacter isolated from broiler chickens

\begin{tabular}{|c|c|c|c|c|c|}
\hline \multirow[b]{3}{*}{ Species } & \multicolumn{5}{|c|}{ Number (\%) identified by } \\
\hline & \multirow[b]{2}{*}{ Culture } & \multirow[b]{2}{*}{$16 \mathrm{~S}$ rRNA un* } & \multirow{2}{*}{$\begin{array}{c}\text { PCR } \\
16 \mathrm{SRNA} \mathrm{ss}{ }^{\dagger}\end{array}$} & \multicolumn{2}{|c|}{ Hip $\mathrm{O}^{\ddagger}$} \\
\hline & & & & + & - \\
\hline Campylobacter spp. & 114 & 114 & $\ldots$ & & \\
\hline C. jejuni & $101(88.6)$ & $\ldots$ & 101 & 101 & \\
\hline C. coli & 13 (11.4) & $\ldots$ & 13 & 2 & 11 \\
\hline C. lari & 0 & $\ldots$ & 0 & & \\
\hline C. upsaliensis & 0 & $\ldots$ & 0 & & \\
\hline C. hyointestinalis & 0 & $\ldots$ & 0 & & \\
\hline C. fetus & 0 & $\ldots$ & 0 & & \\
\hline C. helviticus & 0 & $\ldots$ & 0 & & \\
\hline Total & 114 & 114 & 114 & 103 & 11 \\
\hline
\end{tabular}

*16S rRNA universal primers.

$\dagger 16 \mathrm{~S}$ rRNA primers for specific species.

Hippuricase gene primers. 
Table 3. Effects of CDT from C. jejuni and C. coli isolates from Danish broilers in Vero and chicken embryo cell tissue culture assays

\begin{tabular}{|c|c|c|c|c|c|c|}
\hline \multirow[b]{3}{*}{ Species } & \multirow{3}{*}{$\begin{array}{c}\text { Number of } \\
\text { isolates }\end{array}$} & \multirow{3}{*}{$\begin{array}{c}c d t \text { genes } \\
\text { detected } \\
(\%)\end{array}$} & \multicolumn{4}{|c|}{ Tissue culture assays for $\mathrm{CDT}^{*}$} \\
\hline & & & \multicolumn{2}{|c|}{ Vero } & \multicolumn{2}{|c|}{ Chicken embryo } \\
\hline & & & + & - & + & - \\
\hline C. jejuni & 101 & $\begin{array}{c}101^{\dagger} \\
(100)\end{array}$ & 100 & 1 & 89 & 12 \\
\hline C. coli & 13 & $\begin{array}{c}13 \\
(100)\end{array}$ & 10 & 3 & 10 & 3 \\
\hline Total & 114 & 114 & 110 & 4 & 99 & 15 \\
\hline
\end{tabular}

* The effect of CDT on tissue culture assays was determined as described in Materials and methods.

${ }^{\dagger}$ The $c d t$ genes were detected by different primer sets (Fig. 1).

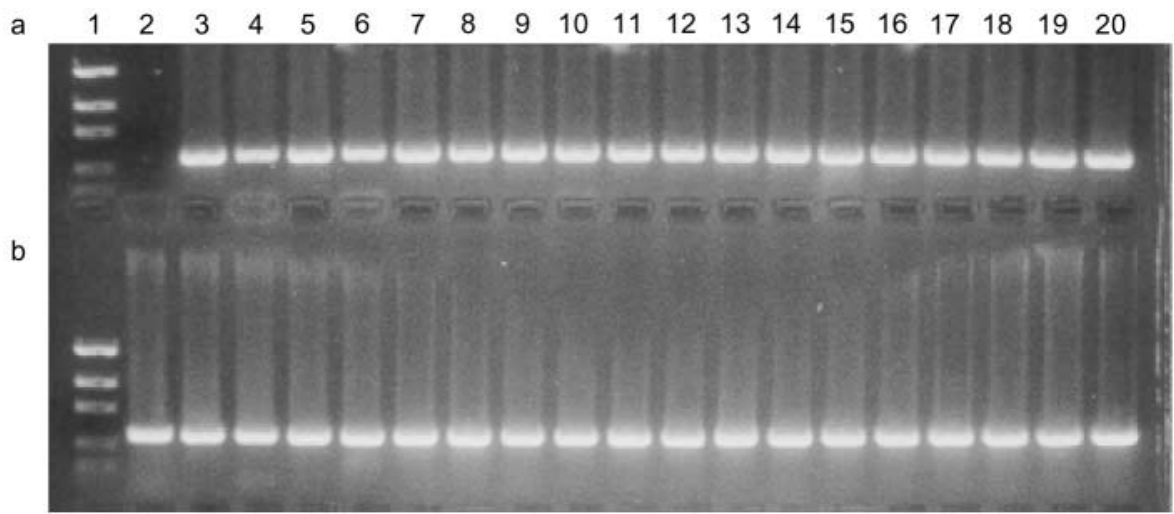

Fig. 2. $c d t$ B-PCR products obtained with primers VAT2(a) and WMI1(b) with Campylobacter DNA as templates. Lane 1 (in a and b), $0.3 \mu \mathrm{g}$ of DNA mass ladder mol. wt standard; 2 (in a), negative control; 20 (in b), positive control with DNA from reference strain C. jejuni CCUG-11284; 3-20 (a) and 2-8 (b), the $c d t$ B-PCR products obtained with different DNA templates from $C$. jejuni and $C$. coli $(\mathbf{9}-\mathbf{1 9}$ in b) isolates from Danish broilers.

$c d t \mathrm{~B}$ by these primers (Fig. 1). Two PCR amplicons from each species were selected randomly and purified for sequencing. The sequencing data of these PCR amplicons confirmed that the 500-bp PCR products represented an amplified product from the $c d t \mathrm{~B}$ gene of both selected $C$. jejuni and $C$. coli isolates.

The three C. jejuni isolates SC-6, SC-61 and SC-770, that were $c d t \mathrm{~B}-\mathrm{PCR}$-negative with VAT2-WMI1 primers, were screened for $c d t$ genes with different primer combinations (GNW-IVH or VAT2-LPFX); PCR products of $165 \mathrm{bp}$ and $1050 \mathrm{bp}$, respectively, were amplified with the DNA from these three strains.

Differentiation of $C$. jejuni from $C$. coli by restriction analysis of $c d t B$ gene $P C R$ product with EcoRI

It has been shown that the sequence of the 500-bp $c d t \mathrm{~B}$ gene from selected $C$. jejuni strains contains an EcoRI restriction site, whereas this restriction site is not present in the $c d t \mathrm{~B}$ sequences of some $C$. coli strains [34]. The EcoRI restriction endonuclease fragment patterns of 500-bp PCR products of all the isolates were examined. The 500-bp PCR products of all the $C$. jejuni, including the hippuricase-positive $C$. coli isolates tested, were cut once with EcoRI generating 350bp and 150-bp fragments, whereas none of the 500-bp PCR products from hippuricase-negative $C$. coli was cut (Fig. 3).

\section{Vero and chicken embryo cell assay results}

In the Vero cell assay, $100(99 \%)$ of 101 C. jejuni isolates produced $\mathrm{CDT}$; one $C$. jejuni isolate (SC-6) produced no toxin. However, with chicken embryo cells, $89(88.1 \%)$ of the isolates produced CDT and 12 (11.8\%) produced little or no CDT. Of 13 C. coli isolates, 10 isolates produced CDT in both assays, whereas three isolates produced no toxin in either Vero or chicken embryo cell assays (Table 3). The CDT titres produced by different isolates were determined by performing two-fold serial dilutions of the cell-free supernates on Vero cells and it was observed that the CDT activities differed among isolates. Of $101 \mathrm{C}$. jejuni isolates, $47(46.5 \%)$ isolates produced a CDT titre of 1 in $64,25(24.7 \%)$ isolates produced a CDT titre of 1 in $32,24(23.7 \%)$ isolates produced a titre of 1 in 16, $4(3.9 \%)$ isolates produced a CDT titre of 1 in 8 and one was negative. However, the $C$. coli isolates 


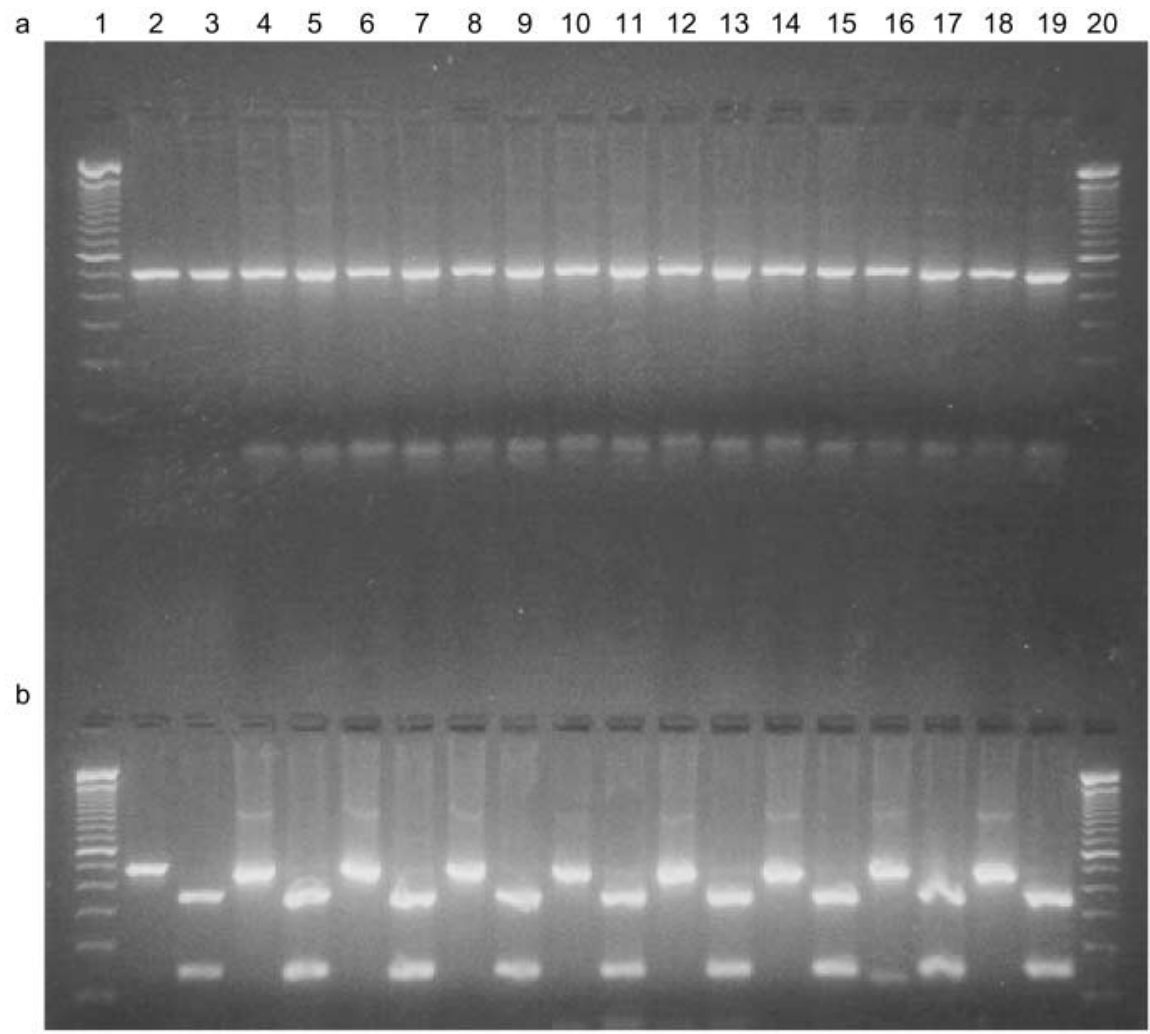

Fig. 3. EcoRI restriction of $c d t \mathrm{~B}$ gene PCR products from representative $C$. coli (a) and $C$. jejuni (b) chicken isolates. Lanes 1 and 20 (a and b), $0.3 \mu \mathrm{g}$ of 100-bp DNA ladder mol. wt standard. (a) $c d t \mathrm{~B}-\mathrm{PCR}$ products from $C$. coli strains. In even lanes, nontreated $c d t$ B-PCR products from $C$. coli strains: CCUG-11283, SC-732, SC-733, SC-734, SC-736, SC-737, SC-738, SC-739, SC741, and in odd lanes, EcoRI-treated PCR products from the same strains, respectively. (b) $c d t \mathrm{~B}-\mathrm{PCR}$ products from $C$. jejuni isolates. In even lanes, non-treated $c d t$ B-PCR products from $C$. jejuni strains CCUG-11284, SC-328, SC-333, SC-335, SC-357, SC-360, SC-418, SC-452, SC-637 and in odd lanes EcoRI-treated PCR products from the respective strains.

produced much lower CDT titres. Of 13 C. coli isolates originating from four flocks, 3 produced no toxin, 9 produced a CDT titre of 1 in 8 , and only one isolate produced a CDT titre of 1 in 16 (Fig. 4).

\section{Discussion}

In this study, the frequency of different Campylobacter species in individual chickens was investigated. Campylobacter isolates were identified to species level by two techniques - conventional phenotypic character-

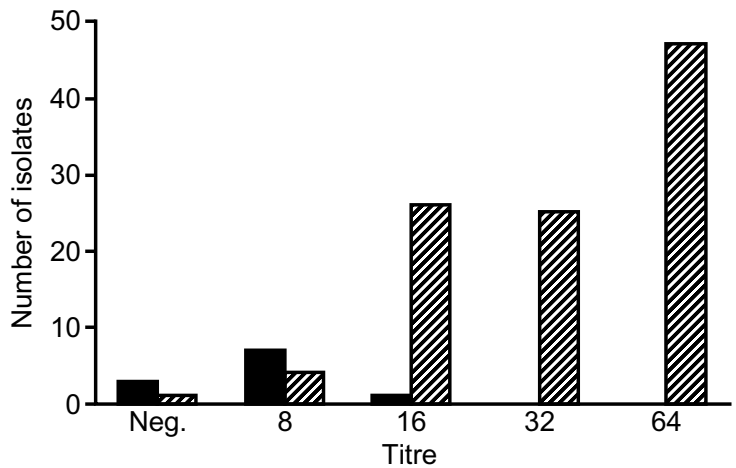

Fig. 4. CDT titre produced by Campylobacter spp. isolated from Danish broilers, $\mathbf{\square}$, C. coli; $\mathbb{Z}$, C. jejuni. isation and PCR. Identification by conventional methods is laborious and time-consuming (c. 2-3 days). However, Campylobacter spp. can be identified within $10-15 \mathrm{~h}$ by the PCR method described above, [35]. The results of the two methods were essentially in agreement except that two isolates identified as $C$. coli by conventional methods (hippurate hydrolysis negative) were positive by hippuricase-PCR, suggesting that they were hippurate hydrolysis-negative $C$. jejuni. Such strains have been described as variants of $C$. jejuni containing a mutation in the hippuricase gene [30].

The data from EcoRI restriction endonuclease analysis of the $c d t \mathrm{~B}$ PCR products in this study confirmed that all $103 C$. jejuni isolates tested - including the two hippuricase PCR-positive $C$. coli isolates - contained the EcoRI restriction site, whereas this restriction site was absent in $11 C$. coli isolates. In view of these results PCR with hippuricase primers and EcoRI restriction analysis of $c d t \mathrm{~B}-\mathrm{PCR}$ amplicons may be useful for establishing species identity of these two closely related species. Taken together, the results of all the methods indicated that $90.4 \%$ of the isolates were C. jejuni and $9.6 \%$ were C. coli. No other Campylobacter sp. was isolated. The results confirmed the predominance of $C$. jejuni among strains isolated from broilers. 
Recently, several publications have reported on the frequency of $c d t$ genes among Campylobacter isolates from different sources $[17,18,34,36-38]$. Little is known about the frequency of these toxin genes among Campylobacter isolates from broilers. In this study, the prevalence and expression of the $c d t$ genes in Campylobacter isolates from Danish broilers was determined. A PCR method was used to detect the $c d t \mathrm{~B}$ gene in the Campylobacter isolates. With the combination of VAT2-WMI1 primers, the $c d t \mathrm{~B}$ gene was detected in 111 of 114 isolates. The $c d t \mathrm{~B}$ genes of the three C. jejuni isolates, SC-6, SC-61 and SC-770, were detected only when different primer sets complementary to the $c d t \mathrm{~A}$ and $c d t \mathrm{C}$ genes were used. Testing for CDT production by the 114 isolates with cell culture assays revealed that one of the three $c d t \mathrm{~B}$ PCR-negative isolates (C. jejuni SC-6) was the only $C$. jejuni isolate that did not produce CDT, either in Vero or in chicken embryo cell assays. Strains SC-61 and SC-770 produced CDT, but with very low titres. The fact that the $c d t$ genes of these three isolates were amplified only with different primer sets and that they produced little or no CDT toxin could be the result of a mutation in the coding region of $c d t \mathrm{~B}$ gene in these isolates. This may have influenced the production of active CDT by these isolates as well as the annealing of primer WMI1 to the $c d t \mathrm{~B}$ gene in the PCR tests.

The production of CDT by the isolates was also tested with Vero and chicken embryo cells. In all, 110 (96\%) of 114 Campylobacter isolates produced CDT in the Vero cell test, whereas only $99(86.8 \%)$ of 114 demonstrated CDT production in the chicken embryo cell assay.

The effects of CDT on Vero cells observed in this study were similar to the effects of CDT on Vero cells and Chinese hamster ovary cells observed by others $[16,39]$. All but one of the C. jejuni isolates (100 of 101 ) produced CDT in the Vero cell assays, whereas $C$. coli isolates produced little or no CDT in either Vero or chicken embryo cell assays. The frequency of CDTproducing Campylobacter isolates in this study (96.5\%) was similar to the reported $99 \%$ in one of the previous studies [38], but higher than the frequency of $17 \%$ [18], or $28.6 \%$ found by others [17]. There may be several explanations for this variation. Firstly, the Campylobacter isolates used in this study were fresh isolates. Also, the method of analysis of CDT production in this study was similar to that used by Johnson and Lior [16], who used the unconcentrated culture supernates, but was different from the cell lysate assays used in other studies $[17,21]$. In this study, the cell-free supernates were tested immediately after preparation. Both the Vero and chicken embryo cells used in this study were $<2$ days old after being trypsinised and seeded.

Previous studies have suggested that a substantial proportion of $C$. jejuni strains might not produce
CDT [16]. In this study, nearly all $C$. jejuni isolates produced CDT, although the CDT titre differed among the isolates. However, the Vero cell line used in this study has been tested and shown to be very sensitive to both E. coli Verotoxin [33] and CDT toxin (D. D. Bang and F. Scheutz, unpublished results).

Florin and Antillon [18] suggested that at least two different cell types should be used to detect CDT production by campylobacters. One of the cell lines should be Vero cells and the other could be either HeLa cells or a fibroblast cell line, as these cell lines were considered to be more sensitive. Vero and chicken embryo fibroblast cells were used in the present study. The frequency of CDT-producing Campylobacter isolates on chicken embryo fibroblast cells in the present study was lower than that obtained in the Vero cell assays. This could be due to the high cell densities $\left(0.5 \times 10^{8}\right.$ cells $\left./ \mathrm{ml}\right)$ used in chicken fibroblast assays. We have observed a large cell density-dependent difference in the sensitivity of CDT detection (D. D. Bang and K. Handberg, unpublished results).

In conclusion, the results presented here confirm the very common occurrence of $C$. jejuni and $C$. coli in broiler chickens and indicate that the $c d t$ genes may frequently be present in both $C$. jejuni and $C$. coli isolates from broilers. However, the role of CDT in campylobacteriosis is still in question. The study of regulation and expression of the $c d t$ genes in vivo and in vitro, especially testing of strains with defined mutations of these genes, in animal models will be of great help to improve the understanding of the role of CDT in the pathogenesis of campylobacteriosis.

The technical assistance of Ms A. Brandstrup, M. Hansen, H. E. Christiansen, E. B. Sørensen, G. Lauridsen, S. Pedersen (DVL, Aarhus) and Ms S. Jespersen (International Escherichia and Klebsiella Center (WHO), Statens Serum Institut, Copenhagen) is gratefully acknowledged. We thank Eng. Per Wolff, Professor Brian Mayoh (University of Aarhus) and Dr Niels Lorenzen (DVL, Aarhus) for their critical revision of the manuscript and Alice Wedderkopp and the Danish National Campylobacter surveillance programme for contributing the broiler samples. This work was supported by the Danish Poultry Meat Association and the Danish Ministry of Food, Agriculture and Fisheries. This work was presented in part at the 10th International Workshop on Campylobacter, Helicobacter and Related Organisms, Baltimore, MD, USA, 12-16 September 1999.

\section{References}

1. Blaser MJ, Berkowitz ID, LaForce FM, Cravens J, Reller LB, Wang W-LL. Campylobacter enteritis: clinical and epidemiologic features. Ann Intern Med 1979; 91: 179-185.

2. Blaser MJ, Wells JG, Feldman RA, Pollard RA, Allen JR and the Collaborative Diarrheal Disease Study Group. Campylobacter enteritis in the United States. A multicenter study. Ann Intern Med 1983; 98: 360-365

3. Hald T, Wegener HC, Larsen SK, Flensburg J (eds). Annual report on zoonoses in Denmark 1996. Copenhagen, Denmark, The Danish Zoonosis Centre. 1997.

4. Brøndsted T, Hald T, Bager F (eds). Annual report on zoonoses in Denmark 1999. Copenhagen, Denmark, The Danish Zoonosis Centre. 2000.

5. Deming MS, Tauxe RV, Blake PA et al. Campylobacter enteritis at a university: transmission from eating chicken and 
from cats. Am J Epidemiol 1987; 126: 526-534.

6. Harris NV, Weiss NS, Nolan CM. The role of poultry and meats in the etiology of Campylobacter jejuni/coli enteritis. Am J Public Health 1986; 76: 407-411.

7. Skirrow MB. Diseases due to Campylobacter, Helicobacter and related bacteria. J Comp Pathol 1994; 111: 113-149.

8. Shane SM. Environmental factors associated with Campylobacter jejuni colonization in poultry. In: Blankenship LC (ed) Colonization control of human bacterial enteropathogens in poultry. San Diego, Academic Press. 1991: 29-46.

9. Wedderkopp A, Rattenborg E, Madsen M. National surveillance of Campylobacter in broilers at slaughter in Denmark in 1998. Avian Dis 2000; 44: 993-999.

10. Tauxe RV, Hargrett-Bean N, Patton CM, Wachsmuth IK. Campylobacter isolates in the United States, 1982-1986. Morb Mortal Wkly Rep CDC Surveill Summ 1988; 37: 1-13.

11. Anonymous. Common gastrointestinal tract infections. Commun Dis Rep CDR Wkly 1997; 7: 10.

12. Welkos SL. Experimental gastroenteritis in newly hatched chicks infected with Campylobacter jejuni. J Med Microbiol 1984; 18: 233-248.

13. Walker RI, Caldwell MB, Lee EC, Guerry P, Trust TJ, RuizPalacios GM. Pathophysiology of Campylobacter enteritis. Microbiol Rev 1986; 50: 81-94.

14. Ketley JM. Virulence of Campylobacter species: a molecular genetic approach. J Med Microbiol 1995; 42: 312-327.

15. Wassenaar TM. Toxin production by Campylobacter spp. Clin Microbiol Rev 1997; 10: 466-476.

16. Johnson WM, Lior H. A new heat-labile cytolethal distending toxin (CLDT) produced by Campylobacter spp. Microb Pathog 1988; 4: 115-126.

17. Schulze F, Hanel I, Borrmann E. Formation of cytotoxins by enteric Campylobacter in humans and animals. Zentralbl Bakteriol 1998; 288: 225-236.

18. Florin I, Antillon F. Production of enterotoxin and cytotoxin in Campylobacter jejuni strains isolated in Costa Rica. J Med Microbiol 1992; 37: 22-29.

19. Misawa N, Ohnishi T, Itoh K, Takahashi E. Development of a tissue culture assay system for Campylobacter jejuni cytotoxin and the influence of culture conditions on cytotoxin production. J Med Microbiol 1994; 41: 224-230.

20. Whitehouse CA, Balbo PB, Pesci EC, Cottle DL, Mirabito PM, Pickett CL. Campylobacter jejuni cytolethal distending toxin causes a G2-phase cell cycle block. Infect Immun 1998; 66: 1934-1940.

21. Pickett CL, Pesci EC, Cottle DL, Russell G, Erdem AN, Zeytin H. Prevalence of cytolethal distending toxin production in Campylobacter jejuni and relatedness of Campylobacter spp. $c d t B$ genes. Infect Immun 1996; 64: 2070-2078.

22. Pickett CL. Cytolethal distending toxin causes a G2 phase cell cycle block. In: Abstracts of the 97th Meeting of the American Society for Microbiology 1997. Washington, DC, American Society for Microbiology, 1997; B-259, p. 73.

23. Pérès SY, Marchès O, Daigle F et al. A new cytolethal distending toxin (CDT) from Escherichia coli producing CNF2 blocks HeLa cell division in G2/M phase. Mol Microbiol 1997; 24: 1095-1107.

24. Pickett CL, Whitehouse CA. The cytolethal distending toxin family. Trends Microbiol 1999; 7: 292-297.

25. On SL, Holmes B. Reproducibility of tolerance tests that are useful in identification of campylobacteria. J Clin Microbiol 1991; 29: 1785-1788.

26. On SLW, Holmes B. Assessment of enzyme detection tests useful in identification of campylobacteria. J Clin Microbiol 1992; 30: 746-749.

27. Linton D, Owen RJ, Stanley J. Rapid identification by PCR of the genus Campylobacter and of five Campylobacter species enteropathogenic for man and animals. Res Microbiol 1996; 147: 707-718.

28. Linton D, Lawson AJ, Owen RJ, Stanley J. PCR detection, identification to species level, and fingerprinting of Campylobacter jejuni and Campylobacter coli directly from diarrheic samples. J Clin Microbiol 1997; 35: 2568-2572.

29. Slater ER, Owen RJ. Restriction fragment length polymorphism analysis shows that the hippuricase gene of Campylobacter jejuni is highly conserved. Lett Appl Microbiol 1997; 25: 274-278.

30. Hani EK, Chan VL. Expression and characterization of Campylobacter jejuni benzoylglycine amidohydrolase (hippuricase) gene in Escherichia coli. J Bacteriol 1995; 177: 2396-2402.

31. Schat KA, Purchase HG. Cell culture methods. In: Purchase $\mathrm{HG}$, Lawrence HA, Domermuth $\mathrm{CH}$, Pearson JE (eds) A laboratory manual for the isolation and identification of avian pathogens. American Association of Avian Pathologists. Dubuque, Iowa, Kendall/Hunt Publishing Co. 1989: $167-175$.

32. Konowalchuk J, Speirs JI, Stavric S. Vero response to a cytotoxin of Escherichia coli. Infect Immun 1977; 18: 775-779.

33. Scheutz F. Vero cytotoxin producing Escherichia coli (VTEC) isolated from Danish patients. PhD thesis, Department of Gastrointestinal Infections, Statens Serum Institut, Copenhagen, Denmark. 1997.

34. Eyigor A, Dawson KA, Langlois BE, Pickett CL. Cytolethal distending toxin genes in Campylobacter jejuni and Campylobacter coli isolates: detection and analysis by PCR. J Clin Microbiol 1999; 37: 1646-1650.

35. Bang DD, Madsen M. Development of a PCR detection method suitable for mass screening program for Campylobacter spp. in Danish broiler production. In: Abstracts of the 20th Gala International Workshop on Rapid Methods and Automation in Microbiology July 7-14, 2000, Kansas State University, Manhattan, Kansas, USA. 2000.

36. McFarland BA, Neill SD. Profiles of toxin production by thermophilic Campylobacter of animal origin. Vet Microbiol 1992; 30: 257-266.

37. Ohya T, Tominaga K, Nakazawa M. Production of cytolethal distending toxin (CDLT) by Campylobacter fetus subsp. fetus isolated from calves. $J$ Vet Med Sci 1993; 55: 507-509.

38. Eyigor A, Dawson KA, Langlois BE, Pickett CL. Detection of cytolethal distending toxin activity and $c d t$ genes in Campylobacter spp. isolated from chicken carcasses. Appl Environ Microbiol 1999; 65: 1501-1505.

39. Aragon V, Chao K, Dreyfus LA. Effect of cytolethal distending toxin on F-actin assembly and cell division in Chinese hamster ovary cells. Infect Immun 1997; 65: 3774-3780. 